\title{
Inhibition of Peroxidase Activity by Methylxanthines
}

\author{
Tayyebeh Rahmati Darvazi ${ }^{1}$, Abdolali Varasteh${ }^{1}$, Reyhaneh Sariri' ${ }^{*}$ \\ ${ }^{1}$ Department of Biology, Faculty of Science, University of Guilan, Rasht, Iran
}

Corresponding Author: Reyhaneh Sariri, Professor, Department of Biology, Faculty of Science, University of Guilan, Rasht, Iran. Tel/ Fax: 01333333647, Email: sariri@guilan.ac.ir

Received April 18, 2018; Accepted July 3, 2018; Online Published September 30, 2018

\begin{abstract}
Introduction: Peroxidase (POD) is an important antioxidant enzyme that catalyzes oxidation of a number of organic and non-organic substrates using hydrogen peroxide as the electron acceptor. At physiological low levels, reactive oxygen species (ROS) can act as redox messengers in the regulation of intracellular signaling. However, in excess amounts they can suppress the immune system and cause oxidative stress. Considering the high consumption of tea and coffee as the most common drink in the world, in the present study the effect of caffeine and theophylline on the activity of POD has been investigated.

Materials and Methods: The activity of POD was measured by following absorption at $510 \mathrm{~nm}$ due to the oxidation of 4-aminoantipyrine in the absence and presence of caffeine and theophylline. The enzyme kinetic parameters were then measured and compared in each case.

Results: It was shown that both methylxanthines acted as inhibitors with $\mathrm{IC}_{50^{\prime}}$ the amount of inhibitor to reduce the enzyme activity by $50 \%$, of 0.6 and $\mathrm{mM} 0.55 \mathrm{mM}$ for caffeine and theophylline respectively. The kinetic constants, $\mathrm{K}_{\mathrm{m}}$ and $\mathrm{V}_{\text {max }}$ indicated that both inhibitors worked by an un-competitive mechanism on POD activity. The values of $\mathrm{K}_{\mathrm{i}}$ were calculated as 0.08 and $0.045 \mathrm{mM}$ for caffeine and theophylline respectively.

Conclusions: Lower values of $\mathrm{IC}_{50}$ and $\mathrm{Ki}$ for theophylline compared to caffeine, led us to a final conclusion that theophylline is a stronger inhibitor of POD than caffeine.

Keywords: Peroxidase, Inhibition, Methylxanthines, Theophylline, Caffeine

Citation: Rahmati Darvazi T, Varasteh A, Sariri R. Inhibition of peroxidase activity by methylxanthines. J Appl Biotechnol Rep. 2018;5(3):112-116. doi:10.29252/jabr.05.03.05.
\end{abstract}

\section{Introduction}

Peroxidase is an important antioxidant enzyme that catalyzes the oxidation reactions of various organic and non-organic substrates using hydrogen peroxide as an electron receptor. In common with all heme PODs, it has a general catalytic cycle, with three successive reduction steps. During an initial step, the native enzyme is oxidized by $\mathrm{H}_{2} \mathrm{O}_{2}$ in by a twoelectron transfer reaction. The result is reduction of hydrogen peroxide and production of water. The cationic radical of compound $\mathrm{I}$ is then reduced by $\mathrm{AH}_{2}$ as the electron donor substrate. That $\mathrm{AH}_{2}$ adds one electron to compound I which is converted to compound II. ${ }^{1}$ Hydrogen peroxide is one of the members of reactive oxygen species (ROS), a group of reactive molecules or ions derived from molecular oxygen during the normal metabolism of the cell. Interestingly, the low or moderate concentrations of ROS could play a physiological role in response to cellular damages. On the other hand, the harmful effects of free radicals, such as oxidative stress, occur at their high concentrations. Long term contact with free radicals, even at a low level, can damage the important biological molecules and causes DNA mutation which leads to development of important diseases such as various cancers. ${ }^{2}$ Despite the fact that oxygen is essential for an aerobic life, it can be toxic under certain conditions. This natural effect is known as the "oxygen paradox".

Tea, coffee and soft drinks are consumed as conventional beverages in a daily basis all over the world. Both drinks contain high amounts of chemicals known as methylxanthines, with the most famous members of the group being caffeine (1, 3, 7-trimethyl-xanthine) and theophylline (1,3-dimethylxanthine). When used in a controlled dose, these compounds have beneficial roles in different medical conditions.

Theophylline is clinically used for treating obstructive pulmonary disease and severe asthma due to its known anti-inflammatory and immunomodulatory effects at therapeutic concentrations. ${ }^{6}$ It can prevent the translocation of the transcription factor $-\mathrm{kB}$ in the nucleus, responsible for the transcription of inflammatory genes. It, therefore, can potentially reduce the expression of inflammatory genes in asthma. ${ }^{7,8}$ However, despite to its beneficial effects, high consumption of theophylline can cause harmful effects on the body. ${ }^{9}$

The use of caffeine at a moderate level could increase the brain function and act as anti-depressant agent. It can be prescribed for treatment of Parkinson, Alzheimer's and other disorders of central nervous system..$^{10}$ Its anti-depressant effect and the positive impact on the Parkinson's disease are related to the interaction with dopaminergic systems. Caffeine can disrupt the function of these receptors by blocking adenosine $\mathrm{Al}$ and A2 receptors, which, thus, protects the dopaminergic neurons. On the other hand, main cause of depression and Parkinson's disease, is the reduced to the activity of dopaminergic systems

Copyright $\odot 2018$ The Author(s). This is an open-access article distributed under the terms of the Creative Commons Attribution License (http:// creativecommons.org/licenses/by/4.0), which permits unrestricted use, distribution, and reproduction in any medium, provided the original work is properly cited. 
and destruction of dopaminergic neurons. Blocking these receptors, gives the molecule an analgesic effect. ${ }^{11,12}$ Caffeine can also exhibit antioxidant activity through inhibition of lipid peroxidation, an action which opposes the function of ROS. However, the overuse of caffeine can be harmful, increasing the chance of oxidative stress and lipid peroxidation. It has been demonstrated that chronic administration of caffeine could significantly increase activities of hepatic antioxidant enzymes of Ehrlich ascites tumor-bearing mice. ${ }^{13}$ The aim of our present research was investigating the possible effect of two most commonly used methylxanthines, caffeine and theophylline, on biological activity of POD in vitro.

\section{Materials and Methods}

Materials

Arthromyces ramosus POD, caffeine, theophylline and 4-aminoantipyrine were purchased from Sigma-Aldrich, phenol supplied from Merck and hydrogen peroxide 30\% from Dr. Mojallali Chemical Industry. The potassium phosphate buffer was prepared freshly in the laboratory. The UV-Visible spectrophotometer was model 3000 Ultrospec from Pharmacia Company.

\section{Assay of Peroxidase Activity}

The activity of POD was measured by the Caesar's method with a slight modification. ${ }^{14}$ One microliter of enzyme solution was added to the reaction solution containing $340 \mu \mathrm{L}$ phenol 0.17 $\mathrm{M}, 1.7 \mu \mathrm{L}$ of hydrogen peroxide $1.7 \mathrm{mM}, 4$-amino antipyrine $2.5 \mathrm{mM}(1,2,3,5,8,10,15,20,30,50,100 \mu \mathrm{M})$ and potassium phosphate buffer $0.2 \mathrm{M}$ ( $\mathrm{pH}$ 7.2). A chromogen product was formed as the result of POD catalyzed oxidation of 4-amino antipyrine in the presence of phenol and hydrogen peroxide. Formation of the product was then followed by recording the change of absorption $(\Delta \mathrm{A} / \mathrm{min})$ of the mixture at $510 \mathrm{~nm}$ and $25^{\circ} \mathrm{C}$ for 3 minutes. ${ }^{15}$ The Michaelis-Menten and LineweaverBurk plots were obtained using the average value obtained from these data and the kinetic constants, $\mathrm{K}_{\mathrm{m}}$ and $\mathrm{V}_{\text {max }}$, were calculated accordingly. Each experimental stage was repeated in triplicate.

\section{Enzyme Inhibition}

In this experiment, the concentrations of phenol, hydrogen peroxide and 4-amino antipyrine $(100 \mu \mathrm{M}$, saturation concentration) were kept constant and the inhibitor concentration varied from 0.2 to $2 \mathrm{mM}$ for caffeine and 0.25 to $1.5 \mathrm{mM}$ for theophylline. As mention before, in this study we repeated the test three times. The results indicated a reduced activity of the enzyme in both cases. Using the average results, plots of inhibition and dose-response were obtained for each inhibitor.

\section{Kinetic Parameters}

The value of $\mathrm{IC}_{50}$ was calculated from the dose-response plot for each inhibitor. In order to study the type of inhibition and validate $\mathrm{K}_{\mathrm{m}}$ and $\mathrm{V}_{\max }$, the enzyme activity at different concentrations of substrate (from 1 to $100 \mu \mathrm{M}$ ) and constant concentration of each inhibitor was measured. To measure values of kinetic constants and investigate the type of inhibition, i.e. partial or complete, the linear plots, Lineweaver-Burk and Dixon, were obtained for both inhibitors.

\section{Results}

According to the results, different concentrations of both caffeine and theophylline reduced the activity of POD (Figure 1).

Determination of Kinetic Parameters, $\mathrm{K}_{\mathrm{m}}$ and $\mathrm{V}_{\max }$ The values of $\mathrm{K}_{\mathrm{m}}$ and $\mathrm{V}_{\text {max }}$ were calculated from LineweaverBurk plots in the absence and presence of inhibitors (Figure 2 and Figure 3 for caffeine and theophylline respectively). The kinetic parameters thus obtained are compared in Table 1.

To determine accuracy of $\mathrm{K}_{\mathrm{m}}$ and $\mathrm{V}_{\max }$, Hanes-Woolf plots were also plotted in the presence and absence of each inhibitor at their $\mathrm{IC}_{50}$ and $\mathrm{K}_{\mathrm{m}}$ and $\mathrm{V}_{\max }$ were extracted from them too. It was noticed that $\mathrm{K}_{\mathrm{m}}$ and $\mathrm{V}_{\max }$ values calculated by both Hanes-Woolf and Lineweaver-Burk plots exactly confirmed each other. The plots and kinetic constants are not presented here.

It is known that the Lineweaver-Burk plot is linear for both partial and complete inhibition and is not suitable, therefore, to show the type of inhibition. However, Dixon plot $(1 / \mathrm{V}$ against [I]) is only linear if a complete inhibition is occurred. It is, thus, one of the best ways to exactly confirm partial or complete inhibition. ${ }^{15}$ Figure 4 and Figure 5 show the Dixon

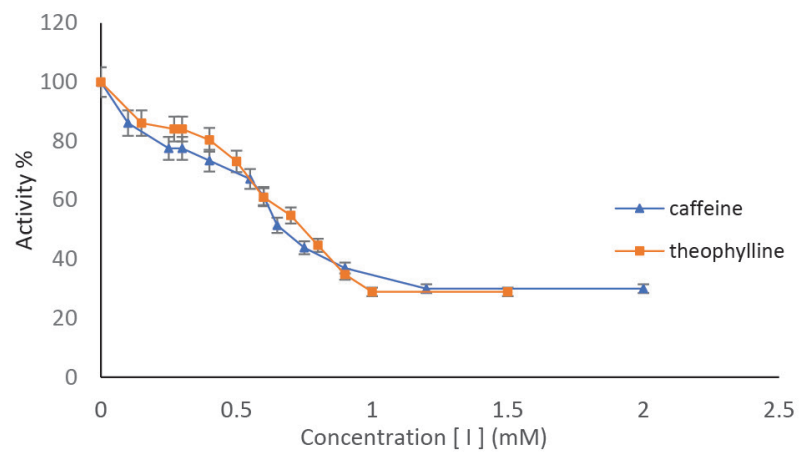

Figure 1. Reduction of Peroxidase Activity in the Presence of $0.1-2 \mathrm{mM}$ of Caffeine and 0.15-1.5 mM of Theophylline at $25^{\circ} \mathrm{C}$.

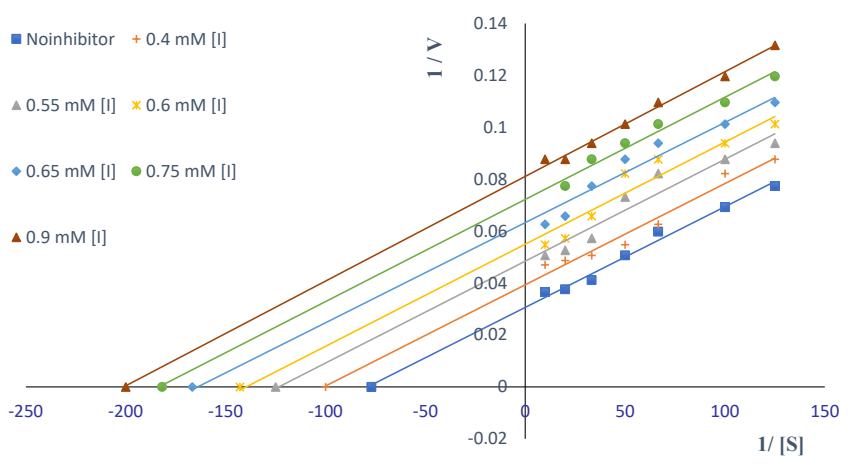

Figure 2. Lineweaver Burk Plots in the Absence and Presence of Inhibitors for Caffeine at $25^{\circ} \mathrm{C}, 0.2 \mathrm{mM}$ Buffer, $\mathrm{pH} 7.2,0.17 \mathrm{M}$ Phenol, $1.7 \mathrm{mM}$ $\mathrm{H}_{2} \mathrm{O}_{2}$ and $2.5 \mathrm{mM}$ 4-Amino Antipyrine. The paralleled lines are indicative of uncompetitive mechanism. 


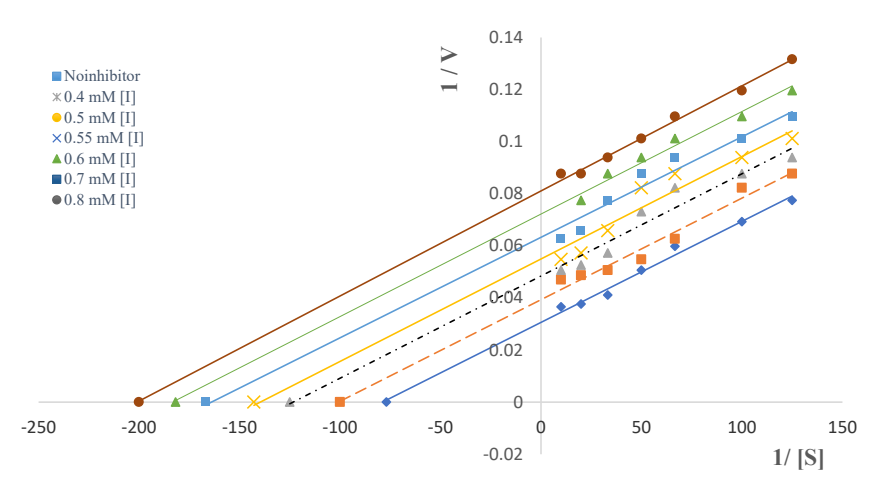

Figure 3. Lineweaver Burk Plots in the Absence and Presence of Inhibitors for Theophylline at $25^{\circ} \mathrm{C}, 0.2 \mathrm{mM}$ Buffer, $\mathrm{pH} 7.2,0.17 \mathrm{M}$ Phenol, $1.7 \mathrm{mM}$ $\mathrm{H}_{2} \mathrm{O}_{2}$ and $2.5 \mathrm{mM}$ 4-Amino Antipyrine.

plots for caffeine and theophylline respectively. It was found that in both cases the Dixon plots were linear confirming a complete inhibition type by both methylxanthines.

Determination of $\mathrm{IC}_{50}$ and $\mathrm{K}_{\mathrm{i}}$ values

According to the plots of inhibition (Figure 1) and doseresponse (Figure 6), the value of $\mathrm{IC}_{50}$ was found to be $0.6 \mathrm{mM}$ and $0.55 \mathrm{mM}$ for caffeine and theophylline respectively.

The value of inhibitor constant, $\mathrm{K}_{\mathrm{i}}$ was obtained from the secondary plots, i.e. $1 / \mathrm{K}_{\mathrm{m}}$ against [I] for both inhibitors (Figure $7)$. It is worth remembering that the inhibitory constant $\left(\mathrm{K}_{\mathrm{i}}\right)$ and $\mathrm{IC}_{50}$ values of a compound are related to the concentration required to reduce the enzyme activity by half. In other words, the $\mathrm{K}_{\mathrm{i}}$ value reflects the binding affinity and the $\mathrm{IC}_{50}$ is related to the functional strength of the inhibitor. In the case of noncompetitive inhibitors, $\mathrm{K}_{\mathrm{i}}$ has the same numerical value as the $\mathrm{IC}_{50}$, while for competitive and uncompetitive inhibition; the $\mathrm{K}_{\mathrm{i}}$ is about half the $\mathrm{IC}_{50}$ 's numerical value. However, the small amount of $\mathrm{K}_{\mathrm{i}}$ indicates a greater binding affinity and require smaller amount of medication to inhibit the activity of the enzyme. ${ }^{16}$ As gathered in Table 2, different amounts of $\mathrm{IC}_{50}$ and $\mathrm{K}_{\mathrm{i}}$ for the selected inhibitors were obtained in the present research.

\section{Discussion}

As stated above, low to moderate concentration of ROS play important roles in a number of cell processes with beneficial effects. ${ }^{17}$ They can act, for example, as redox messengers in regulation of intracellular signaling. At high concentrations, they can overcome the immune system and cause oxidative stress. ${ }^{18}$ The high reactivity of these species can damage

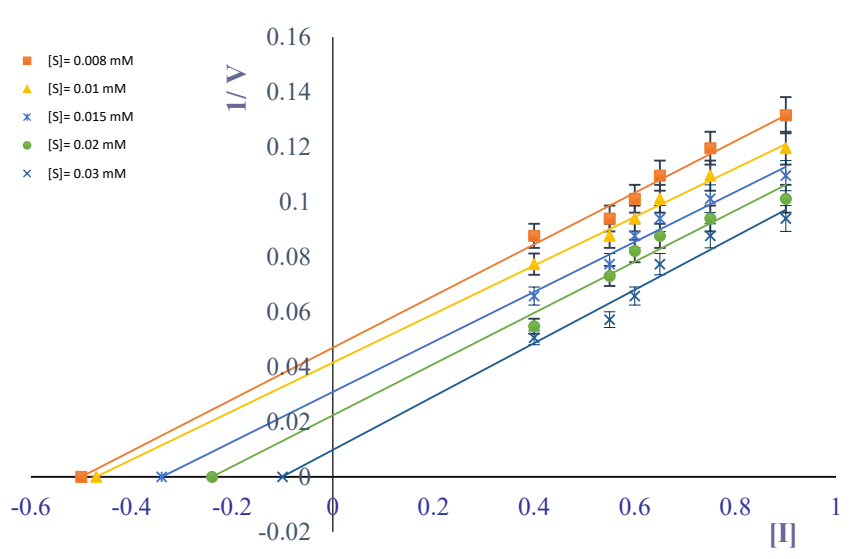

Figure 4. Dixon Plots in the Absence and Presence of Inhibitors for Caffeine at $25^{\circ} \mathrm{C}, 0.2 \mathrm{mM}$ Buffer, $\mathrm{pH} 7.2,0.17 \mathrm{M}$ Phenol, $1.7 \mathrm{mM} \mathrm{H}_{2} \mathrm{O}_{2}$ and $2.5 \mathrm{mM}$ 4-Amino Antipyrine.

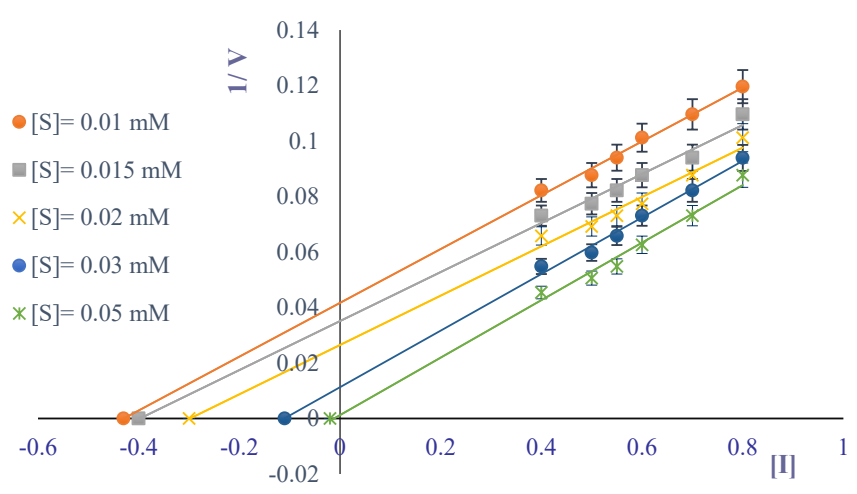

Figure 5. Dixon Plots in the Absence and Presence of Inhibitors for Theophylline at $25^{\circ} \mathrm{C}, 0.2 \mathrm{mM}$ Buffer, $\mathrm{pH} 7.2,0.17 \mathrm{M}$ Phenol, $1.7 \mathrm{mM}$ $\mathrm{H} 2 \mathrm{O} 2$ and $2.5 \mathrm{mM} 4$-Amino Antipyrine.

important biological molecules such as proteins, DNA and carbohydrates leading to dangerous consequences such as cancer. ${ }^{19}$ The body protects the cells against the toxic effects of ROS by neutralizing the excess free radicals. ${ }^{20} \mathrm{POD}$ is an important component of the antioxidant defense system. ${ }^{14,21}$ Tea and coffee contain high amounts of methylxanthines such as caffeine and theophylline which, depending on the dose, could have beneficial or destructive effects on various parts of the body. ${ }^{11,12}$ In this study we found that caffeine and theophylline, have an inhibitory effect on the POD activity. The kinetic parameters, $\mathrm{K}_{\mathrm{m}}$ and $\mathrm{V}_{\text {max }}$, extracted from LineweaverBurk plots (Table 1) indicated that both compounds followed uncompetitive mechanism of inhibition. On the other hand, according to $\mathrm{IC}_{50}$ and $\mathrm{K}_{\mathrm{i}}$ values obtained from dose-response

Table 1. A Comparison of the $\mathrm{K}_{\mathrm{m}}$ and $\mathrm{V}_{\text {max }}$ Values Obtained From Lineweaver-Burk Plots in the Presence of Caffeine and Theophylline

\begin{tabular}{|c|c|c|c|c|c|c|c|}
\hline [Caffeine] (mM) & 0 & 0.4 & 0.55 & 0.6 & 0.65 & 0.75 & 0.9 \\
\hline $\mathrm{K}_{\mathrm{m}}(\mathrm{mM})$ & 0.013 & 0.010 & 0.008 & 0.007 & 0.006 & 0.0055 & 0.005 \\
\hline $\mathrm{V}_{\max }(\mu \mathrm{mol} / \mathrm{min})$ & 31.948 & 25.188 & 20.964 & 18.726 & 16.155 & 13.908 & 12.239 \\
\hline [Theophylline] (mM) & 0 & 0.4 & 0.5 & 0.55 & 0.6 & 0.7 & 0.8 \\
\hline $\mathrm{K}_{\mathrm{m}}(\mathrm{mM})$ & 0.013 & 0.010 & 0.009 & 0.008 & 0.007 & 0.006 & 0.005 \\
\hline $\mathrm{V}_{\max }(\mu \mathrm{mol} / \mathrm{min})$ & 31.948 & 24.509 & 21.834 & 19.801 & 17.857 & 15.267 & 12.886 \\
\hline
\end{tabular}




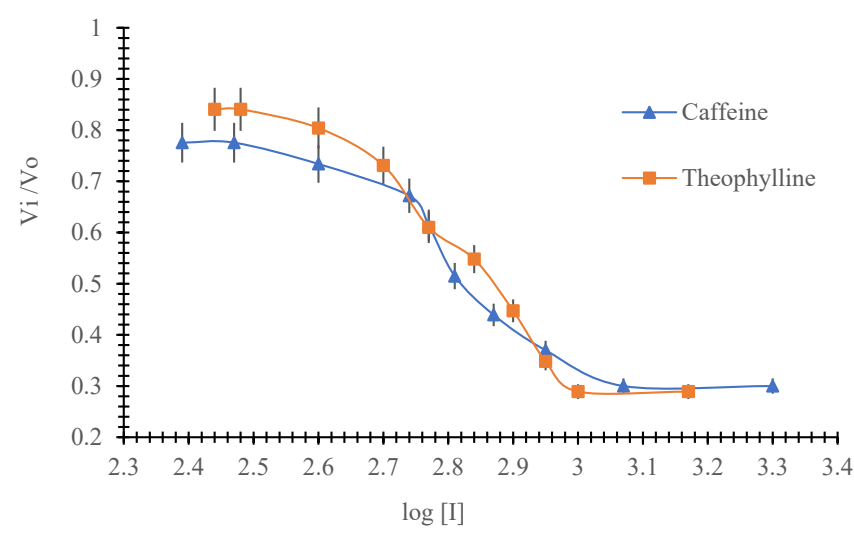

Figure 6. The Dose-Response Plot of Peroxidase in Presence of Caffeine and Theophylline at $25^{\circ} \mathrm{C}$.

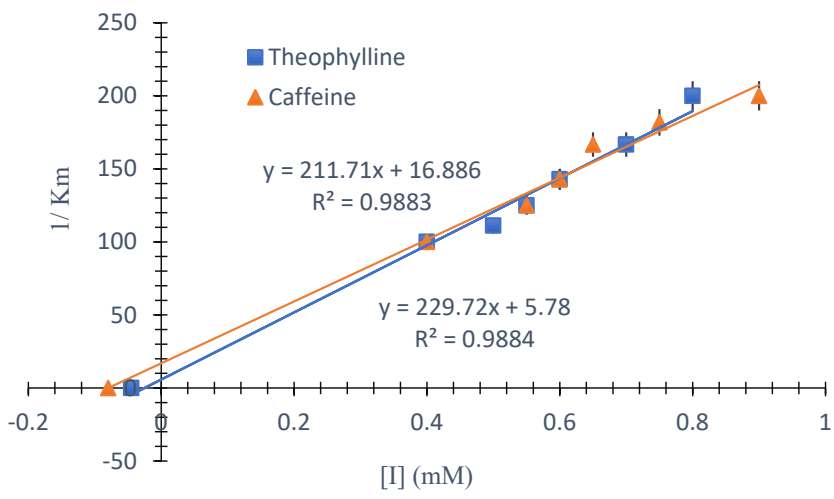

Figure 7. Secondary Plot of Peroxidase in the Presence of Inhibitors at $25^{\circ} \mathrm{C}, 0.2 \mathrm{mM}$ Buffer, $\mathrm{pH} 7.2,0.17 \mathrm{M}$ Phenol, $1.7 \mathrm{mM} \mathrm{H} 2 \mathrm{O} 2$ and $2.5 \mathrm{mM}$ 4-Amino Antipyrine.

Table 2. The Value of $\mathrm{IC}_{50}$ and $\mathrm{K}_{\mathrm{i}}$ for Effect of Caffeine and Theophylline on Peroxidase

\begin{tabular}{llll}
\hline Inhibitor's Name & Chemical Structure & $I_{50}(\mathrm{mM})$ & $\mathrm{K}_{\mathrm{i}}(\mathrm{mM})$ \\
\hline Taffeine & &
\end{tabular}

(Figure 6) and secondary plots (Figure 7) the values of $\mathrm{IC}_{50}$ and $\mathrm{K}_{\mathrm{i}}$ for theophylline is less than caffeine (Table 2). The different numerical values of $\mathrm{IC}_{50}$ and $\mathrm{K}_{\mathrm{i}}$ confirm the uncompetitive mechanism for the inhibition mechanism in both cases. ${ }^{16}$ Therefore, inhibition strength and binding tendency to the enzyme-substrate complex for theophylline is more than caffeine. Considering the chemical structures of the selected compounds (Table 2), it can be suggested that higher inhibition strength of theophylline is possibly related to bulky groups in N1, N3 and N7 positions. Substitution of a bulky group in $\mathrm{N} 1$ and $\mathrm{N} 7$ positions of purine has an important role in the binding tendency of inhibitors to the enzyme. Therefore, the difference in inhibition could be the result the whole structure of each inhibitor. On the other hand, it is known that in the case of complete inhibition, Dixon plot is linear whereas in partial inhibition the Dixon plot is hyperbolic. ${ }^{15}$ Therefore, obtaining the Dixon plots could help to study the type of inhibition. According to our results the Dixon plots for both inhibitors were linear (Figures 4 and 5). We concluded that caffeine and theophylline acted by a complete inhibition type. This type of result was also found by a group of researchers who investigated the effect of caffeine on antioxidant enzymes in mouse liver. ${ }^{22}$ They reported that caffeine has an inhibitory effect on the enzyme xanthine oxidase and reduces theirs activity significantly. ${ }^{22}$ In similar investigations on methylxanthines, activity of xanthine oxidase in milk, lung, heart and brain of mouse has been investigated in the presence of caffeine, theophylline and theobromine. ${ }^{23}$ Their results showed that all 3 methylxanthines inhibited the xanthine oxidase activity with competitive mechanism. They also included that based on the $\mathrm{K}_{\mathrm{i}}$ values, theophylline had the highest binding strength to the enzyme with theobromine in the second place followed by caffeine with lowest binding strength to the enzyme. ${ }^{23}$ The effect of methylxanthines including pentoxifylline, theophylline and caffeine has also been investigated on other enzymes such as alkaline phosphatase. ${ }^{24}$ According to results from that study, the tested methylxanthines all reduced the alkaline phosphatase activity by uncompetitive mechanism with theophylline having the highest inhibitory effect. ${ }^{24}$ The effect of caffeine on transferase enzymes including GGT, GPT and GOT has been reported. ${ }^{25}$ They found that caffeine increased the activity of GOT and GPT but inhibited the activity of GGT competitivlye. ${ }^{25}$ Petzer et al have examined the effect of caffeine on the monoamine oxidase. ${ }^{26}$ They reported that caffeine has an inhibitory effect on the monoamine oxidase activity and the type of inhibition was determined to be competitive.

It is a well-known fact that increasing protective mechanisms in neurons can significantly reduce the damage caused by many types of stress. It has been shown that caffeine increases nicotinamide mononucleotide adenylyl transferases (NMNATs) expression both in vitro and in vivo. ${ }^{27}$ As NMNATs is the essential enzyme in biosynthesis of nicotinamide adenine dinucleotide (NAD), the important cofactor in production of many molecular chaperones, its Overexpressing NMNATs can be suggested as a cure for some neurodegenerative disorders. ${ }^{28,29}$

\section{Conclusions}

Based on the results obtained from our research and considering the previous investigations by others, it is concluded that consumption of methylxanthines such as caffeine and theophylline in excess doses, can disrupt the activity of many important enzymes including POD. Altered POD activity would, in turn, put human body more susceptible to abnormalities such as oxidative stress and 
cancer. It is also suggested that, according to $\mathrm{IC}_{50}$ and $\mathrm{K}_{\mathrm{i}}$ values for both inhibitors, theophylline has a stronger negative effect on POD as compared to caffeine.

\section{Authors' Contributions}

All authors contributed equally to this piece of research.

\section{Conflict of Interest Disclosures}

The authors declare they have no conflicts of interest.

\section{Acknowledgments}

A partial financial support by University of Guilan is appreciated.

\section{References}

1. Lin $M$, Nagata $T$, Katahira $M$. High yield production of fungal manganese peroxidases by $E$. coli through soluble expression, and examination of the activities. Protein Express Puri. 2018;145:4552. doi:10.1016/j.pep.2017.12.012.

2. Valko M, Rhodes C, Moncol J, Izakovic M, Mazur M. Free radicals, metals and antioxidants in oxidative stress-induced cancer. Chemico-Biologi Interact. 2006;160(1):1-40. doi:10.1016/j. cbi.2005.12.009.

3. Pisoschi AM, Pop A. The role of antioxidants in the chemistry of oxidative stress: A review. Eur J Med Chem. 2015;97:55-74. 10.1016/j.ejmech.2015.04.040.

4. Gammella E, Recalcati S, Cairo G. Dual role of ROS as signal and stress agents: iron tips the balance in favor of toxic effects. Oxid Med Cell Long. 2016;2016:8629024. doi:10.1155/2016/8629024.

5. Di Meo S, Reed TT, Venditti P, Victor VM. Harmful and beneficial role of ROS. Oxid Med Cell Long. 2016;2016:7909186. doi:10.1155/2016/7909186.

6. Barnes P, Pauwels R. Theophylline in the management of asthma: time for reappraisal? Eur Resp J. 1994;7(3):579-591.

7. Barnes PJ. Theophylline: new perspectives for an old drug. Am J Resp Crit Care Med. 2003;167(6):813-818. doi:10.1164/ rccm.200210-1142PP.

8. Barnes PJ. Theophylline in chronic obstructive pulmonary disease. Proc Am Thorac Soc. 2005;2(4):334-339. doi:10.1513/ pats.200504-024SR.

9. Broeke RT, Leusink-Muis T, Hilberdink R, et al. Specific modulation of calmodulin activity induces a dramatic production of superoxide by alveolar macrophages. Lab Invest. 2004;84(1):2940. doi:10.1038/sj.labinvest.3700002.

10. Lara DR. Caffeine, mental health and psychiatric disorders. J Alzh dis. 2010;20 Suppl 1:239-248. doi:10.3233/JAD-2010-1378.

11. Higdon JV, Frei B. Coffee and health: a review of recent human research. Crit Rev Food Sci Nut. 2006;46(2):101-123. doi:10.1080/10408390500400009.

12. Rivera-Oliver M, Díaz-Ríos M. Using caffeine and other adenosine receptor antagonists and agonists as therapeutic tools against neurodegenerative diseases: a review. Life Sci. 2014;101(1-2):1-9. doi:10.1016/j.Ifs.2014.01.083.

13. Mukhopadhyay S, Mondal A, Poddar MK. Chronic administration of caffeine: effect on the activities of hepatic antioxidant enzymes of Ehrlich ascites tumor-bearing mice. Indi J Exp Biol. 2003;41:283289.

14. Sariri R, Sajedi R, Jafarian V. Inhibition of horseradish peroxidase activity by thiol type inhibitors. J Mol Liq. 2006;123:20-23. doi:10.1016/j.molliq.2005.05.004.

15. Copeland RA. Enzymes: A Practical Introduction to Structure, Mechanism, and Data Analysis. John Wiley \& Sons; 2004

16. Garrett RH, Grisham CM. Biochemistry. Virginia: University of Virginia; 2017:190-214

17. Mittler R. ROS are good. Trends Plant Sci. 2017;22(1):11-19. doi:10.1016/j.tplants.2016.08.002.

18. Bhattacharya S. Reactive oxygen species and cellular defense system. In: Rani V, Yadav U, eds. Free Radicals in Human Health and Disease. New Delhi: Springer; 2015:17-29. doi:10.1007/97881-322-2035-0_2.

19. Valko M, Izakovic M, Mazur M, Rhodes CJ, Telser J. Role of oxygen radicals in DNA damage and cancer incidence. Mol Cell Biochem, 2004;266(1-2):37-56. doi:10.1023/ B:MCBI.0000049134.69131.89.

20. Pham-Huy LA, He H, Pham-Huy C. Free raicals, antioxidants in disease and health. Inter J Biomed Sci. 2008;4(2):89-95.

21. Ikehata K, Buchanan ID, Smith DW. Recent developments in the production of extracellular fungal peroxidases and laccases for waste treatment. J Environ Eng Sci. 2004;3(1):1-19. doi:10.1139/ s03-077.

22. Sung JH, Chang CC, Chang YS. The effect of caffeine on the antioxidative activities of mouse liver. Korean J Food Nutr. 2004;17:442-449.

23. Gibbs BF, Silva IG, Prokhorof A, et al. Caffeine affects the biological responses of human hematopoietic cells of myeloid lineage via downregulation of the mTOR pathway and xanthine oxidase activity. Oncotarhet. 2015;6(30):28678-28692. doi:10.18632/ oncotarget.5212.

24. Glogowski J, Danforth DR, Ciereszeko A. Inhibition of alkaline phosphatase activity of boar semen by pentoxifylline, caffeine, and theophylline. J Androl. 2002;23(6):783-792. doi:10.1002/j.1939-4640.2002.tb02334.x.

25. Al-Qaisi ZHJ, Abbass SAR, Abdullah AH. Effect of caffeine on some transferase enzymes activities. Inter J Chem. 2011:3:140-147.

26. Ali YO, Bradley G, Lu HC. Screening with an NMNAT2-MSD platform identifies small molecules that modulate NMNAT2 levels in cortical neurons. Sci Rep. 2017;7:43846. doi:10.1038/ srep43846.

27. Ali YO, Allen HM, Li-Kroeger $\mathrm{D}$, et al. NMNAT2:HSP90 complex mediates proteostasis in proteinopathies. PLoS Biol. 2016;14(6):e1002472. doi:10.1371/journal.pbio.1002472.

28. Walker LJ, Summers DW, Sasaki Y, et al. MAPK signaling promotes axonal degeneration by speeding the turnover of the axonal maintenance factor NMNAT2. Elife. 2017;6:e22540. doi: 10.7554/eLife.22540.

29. Petzer A, Pienaar A, Petzer JP. The interactions of caffeine with monoamine oxidase. Life Sci. 2013;93(7):283-287. doi:10.1016/j. Ifs.2013.06.020. 